Article

\title{
Tourism Development, Environment and Policies: Differences between Domestic and International Tourists
}

\author{
Jianjun Liu ${ }^{1}$, Haili Pan ${ }^{2,3, *}$ and Shiyong Zheng ${ }^{1}$ \\ 1 Economics and Management School, Wuhan University, Wuhan 430072, China; jianjunliu@whu.edu.cn (J.L.); \\ 2016101050110@whu.edu.cn (S.Z.) \\ 2 Business School, Guilin University of Technology, Guilin 541004, China \\ 3 Research Institute of Modern Enterprise Management, Guilin University of Technology, Guilin 541004, China \\ * Correspondence: phl@glut.edu.cn
}

Received: 9 February 2019; Accepted: 2 March 2019; Published: 6 March 2019

\begin{abstract}
Using panel data from the 17 underdeveloped provinces of China for 2005-2015, the author explored the differential impact of air (environment) quality and government policies on domestic and international visitors. Through econometric model analysis, the authors corroborated that domestic and international visitors react differently to air (environment) quality. In addition, domestic and international tourists have different responses to urbanization and transportation. Marketization is conducive to the development of tourism. Moreover, foreign trade has a positive impact on international tourists. These findings aid local governments to provide additional appropriate tourism development policies.
\end{abstract}

Keywords: tourism; sustainability; marketization; urbanization; environment

\section{Introduction}

In recent years, local governments in China have regarded the development of tourism as a powerful economic policy to promote the sustainable development of the local economy and ecological environment. Tourism can not only bring considerable growth to the economy, but also play an active role in environmental protection. The development of tourism has great potential to improve the economic and environmental sustainability of various provinces [1]. Tourism is a promoter of change and an important economic development choice which makes narrowing the gap between the rich and poor possible [2]. Numerous studies have assessed the economic impact of tourism at the overall (national or regional) level [3,4]. These studies have corroborated that tourism growth led to growth in output and input from tourism-related industries [3]. Currently, many cities in the world attach importance to their tourism strategy [5]. For instance, China has successively promulgated a series of laws and policies to promote the accelerated development of tourism in recent years. The vigorous development of tourism has become a national will and strategy. We affirm that the local and central governments regard development tourism as an important strategy.

The academia has produced considerable research on tourism. However, the majority of these studies independently analyzed domestic and international tourists and found few differences in the natural environment, local government policies, and other factors that affect domestic and international tourists [6-14]. This paper argues that tourists are mainly categorized into two major groups, namely, domestic and international. From the perspective of globalization of the world economy, exchanges between tourists from various countries have become more frequent and numerous, and attracting international tourists is an important means of developing local tourism $[10,15]$. Compared with local tourists, international tourists come from countries and regions with different cultural backgrounds and 
economic development levels. These background differences may cause local tourists and international tourists to react differently to the perceptions and actions of tourism. Then, the background difference between domestic tourists and international tourists may have different attitudes towards some factors affecting tourism, which in turn will affect their willingness to travel and behavior. In this study, we mainly consider two major categories of factors, namely air (environment) quality factors such as carbon dioxide $\left(\mathrm{CO}_{2}\right)$ emissions and PM 2.5 concentrations; and government economic policies such as market-oriented, urbanization, foreign trade, and transportation construction policies. Research has been previously conducted on these factors [7-9,12-14,16]. Although these studies provide a basis for us to understand the impact of these factors on tourism, we aim to investigate whether these effects differ across domestic and foreign visitors. In the case of differences, what are the main differences? For example, air (environment) quality will affect travel for domestic or international tourists. Is it really like this? In addition, should the impact of government policies on domestic and international visitors differ? What factors reflect the difference in impact? To address these questions, we explore impact patterns through analysis of real-time data. This paper uses the macro data at the national level to construct an econometric model to explore the differential impact of the environment and policies on domestic and international tourists. The econometric model combines theory with observational data to provide a robust test for exploring the impact of environmental and policy factors on tourism. We hope that the results of this paper will provide a meaningful reference for local governments and enterprises to implement appropriate tourism policies or marketing strategies.

\section{Theoretical Hypothesis}

Local government economic policies have far-reaching effects on the development of tourism, where certain policies may be beneficial, whereas others may not. This paper mainly discusses the impact of urbanization, marketization, foreign trade, transportation construction, and other policies on domestic and international tourists. Additionally, we explore natural environmental factors, such as the impact of air (environment) quality on domestic and foreign tourists.

Air (environment) quality. The World Tourism Organization recognizes the two-way relationship between tourism and climate change; on the one hand, climate change exerts its impact on tourism destinations and flows. On the other hand, tourism is the main cause of climate change mainly due to the use of fossil fuels that cause greenhouse gas emissions [17-22]. Future tourism growth will increase carbon dioxide emissions, and the increase in carbon dioxide emissions in turn will have a lagging and negative impact on tourism development [6]. The empirical results reveal that as air quality deteriorates, the demand for local outbound tourism increases [10]. Hence, the deterioration of air (environment) quality has weakened people's desire to travel. Zhou et al. (2018) confirmed that air pollution has an adverse impact on the demand for inbound tourism, but this adverse effect varies with the degree of air pollution [14]. Chen et al. (2017) corroborated that during the peak period of tourism, the impact of air pollution on the number of visitors to scenic spots was pronounced [23]. Becken et al. (2017) analyzed self-reported views on the effect of Chinese air quality on tourism by questionnaires. Furthermore, they affirmed that potential travelers expressed negative views on the tourism risks of China, especially air quality. Importantly, the perception of air quality risks had a significant negative impact on the destination's image and intentions to visit China [15]. On the basis of previous research findings and general knowledge, we also argue that air (environment) pollution will have a negative impact on domestic or international visitors.

Urbanization. A country's level of urbanization is related to its level of economic development. Therefore, the higher the level of urbanization, the higher the economic level. Therefore, individuals have more money and ability to pay for travel. Mullins (1991) proposed the concept of tourism urbanization, which was the first study on tourism and urbanization. He believed that the coordinated development of urbanization and tourism could create consumption [24]. In the case of Digha in West Bengal, India, Manojit and Dandapath (2013) corroborated that the increase in road connectivity and transportation services led to the influx of tourists, which led to the development of hotels, holiday 
homes, and private hotels [12]. In addition, Palamalai and Kalaivani (2016) found a causal relationship between urbanization and tourism expansion in India [25]. Similarly, Shinde (2017) used Shirdi in India as an example to examine the urbanization process of religious tourism destinations. Although Shinde discussed tourism as promoting urbanization, Shinde also believed that if urbanization planning cannot be effectively implemented, then it will have an impact on the sustainable development of tourism [26]. Furthermore, Ashworth and Page (2011) affirmed that the global urbanization process will promote the development of leisure service industries including tourism [27]. Naidu (2017) used 30-year (1985-2015) time series data to examine the relationship between urbanization and tourism output. Moreover, he contended that an urbanization growth of $1 \%$ would increase tourism production by $132.87 \%$ in the long run [28]. Although urbanization in a few regions has had different effects on tourism, urbanization has promoted the development of tourism in general [29]. After examining the historical process of urbanization and tourism development, Luo et al. (2016) asserted that urbanization has improved the development of tourism based on a systematic analysis of the relationship between tourism development and urbanization [16]. Thus, this paper posits that urbanization can promote the development of tourism; however, distinguishing the impact of domestic and international tourism is necessary. For domestic tourists, the higher the urbanization, the higher the income level, which increases the possibility of tourism. However, increased urbanization for international tourists means that the locals lose a sense of the original city, culture, and lifestyle and will be inclined to experience the traditional, original style of tourism. Meanwhile, Cuadrado-Ciuraneta et al. (2017) contended that in the Catalonia region of Spain, where the level of urbanization is developed, a phenomenon of tourism suburbanization has emerged in recent years. Moreover, they also confirmed that future research should "... shed light on latent suburbanization processes involving marginal European regions" [30]. Does this mean that tourists from some developed countries or regions in the world tend to return to quiet and leisure suburban life, but the preference for the prosperous areas with higher urbanization level is not so high?Therefore, this study puts forward that urbanization has a positive impact on domestic tourism but a negative impact on international tourism.

Marketization. The marketization process is the core of the functioning of markets [31]. Podedworna (2010) studied the marketization of the Polish economy. Marketization has led to a good development of the Polish economy, especially the rural economy. Further, Podedworna claimed that the third wave of global marketization has promoted the marketization of the natural environment, the commercialization of public goods, and even the marketization of the human body [32]. Marketization is valued by countries, especially those in planned economies. W.Belk and Güliz (1994) studied the marketization and consumer markets of Romania and Turkey in the 1990s. Although differences in culture and development levels exist between the two countries, the marketization process has made both countries show high consumption desires [33]. In the post-industrial era, the consumption symbolism, together with the marketization of the cultural sector, has become increasingly prominent in the service industry [34]. Similar to privatization and commodification, marketization reflects the new characteristics of ecotourism development under the neoliberal mechanism [35]. Andersson and Getz (2009) asserted that tourism is a "mixed industry" where private companies, public institutions, and non-profit associations create tourism products in competition and cooperation [6]. This open tourism development model is the product of the wave of marketization and promotes the development of tourism. One of the most striking changes in the economic reform of China is the non-nationalization of the economy. The increase in the employment share of non-state-owned units is caused by the non-nationalization of state-owned enterprises in urban areas and development of township enterprises in rural areas [36]. The development of township and village enterprises has effectively absorbed the surplus labor of agriculture, which is conducive to increasing the income of rural residents. The resource allocation efficiency of the urban labor market has improved in the process of employment reconstruction. This increase in competitive pressure in the labor market is also conducive to improving organizational efficiency, increasing the wage level of the urban labor market, and increasing the income of residents. Wang et al. (2018) claimed that institutional 
factors have a significant positive impact on the geographical diversity of tourism companies, such as the overall degree of marketization, relationship between local government and market, and degree of product and market development [37]. Therefore, we also agree that marketization can optimize the allocation of tourism resources and improve the efficiency of tourism operations, thereby promoting domestic and international tourism.

Foreign trade. Foreign trade is mainly characterized by frequent international exchanges. The trade structure of China has undergone major changes from its period of reform and opening up. The Chinese economy has become integrated into the international market mainly to promote the development of the manufacturing industry and trade-related financial trade and service industries of China. We validated that foreign trade has enhanced the exchanges between China and the international market, which is conducive for the promotion of the understanding international tourists of China or desires to travel. Hoa et al. (2018) verified that foreign trade and foreign direct investment have a positive impact on tourism [38]. Moreover, Tsui et al. (2018) deduced that bilateral trade volume has positive statistical significance in explaining certain changes in business travel flows [39]. Furthermore, Liu et al. (2018) obtained similar results after studying the tourism market in Thailand, that is, bilateral trade has become an important factor in the inbound tourism flow of the country [10]. Foreign trade is a bilateral development process. In addition to promoting economic interaction between foreign countries and host countries, it can also promote the income and economic development of its residents and may also promote the willingness of domestic residents to travel. However, this effect is more likely to be indirect. Therefore, this article mainly wants to explore the impact of foreign trade on the travel of international tourists to the host country because this impact may be direct. Therefore, we believe that foreign trade has a positive impact on international tourists.

Transportation. Transportation plays an important role in each experience component of travel [40]. As an important part of tourism travel, traffic construction at tourist destinations may have an important impact on tourism. For instance, a strong relationship was found between the development of rail transport and tourism. Railways are associated not only with services, such as hotels and reservations, but also with promoters of tourist destinations [9]. After studying the economic impact of the high-speed railway construction of China, Chang et al. (2018) inferred that railway construction has achieved positive results in terms of economic benefits, social impact, and development sustainability. Railways will bring long-term benefits in the fields of tourism, economy, and transportation [41]. However, Aratuo and Etienne (2019) found a relationship between US economic growth and six tourism-related sub-sectors(i.e., accommodation, air transportation, shopping, food and beverage, other transportation, entertainment, and entertainment).In addition to the accommodation and food and beverage industries, no long-term relationship was found between other tourism sub-sectors and economic growth [7]. We argue that, in contrast to developed countries, China as a developing country is relatively backward in terms of economic level and transportation facilities. Thus, improvement in transportation facilities will contribute to the development of the economy and tourism. In addition, with the development of the economy, the number of private cars owned by Chinese families is increasing. Coupled with the development of the highway, this greatly promotes domestic tourists to travel by car. For international tourists, they usually arrive at the first-tier cities and then transfer to various provincial and city destinations. This long-distance transfer to the railway is still a stable and safe way to travel. Therefore, we believe that transportation can promote the development of tourism. Particularly, compared with railways, highways have a greater impact on domestic tourists; compared with highways, railways have a greater impact on international tourists.

Time trend. In addition to the abovementioned factors, this study uses time trend items to control the possible trend changes in the process of tourism development. 


\section{Models, Methods and Data}

\subsection{Model Building}

This paper takes the economic division of China as an example. The country is divided into Northeast, Central, Eastern, and Western regions according to regional economic development. Relatively speaking, the level of economic development in the eastern region is ahead of the three other regions, where tourism revenue in these regions is a minor component of economic income. Therefore, this study excluded the eastern region from the analysis. The remaining three regions have relatively weak economic levels (economically underdeveloped regions), and the economic levels between regions are only slightly different and rich in tourism resources. Data are lacking in these four regions (Jiangxi, Chongqing, Tibet, Ningxia).Therefore, this paper also excludes the four provinces and cities and the remaining 17 provinces (Northeast: Liaoning, Jilin, and Heilongjiang; Central Region: Shanxi, Anhui, Henan, Hubei, and Hunan; Western Region: Inner Mongolia, Guangxi, Sichuan, Guizhou, Yunnan, Shaanxi, Gansu, Qinghai, and Xinjiang) as the research objects of this paper. The National Bureau of Statistics separately counts tourist arrivals into domestic and international tourists. Therefore, we divide tourists into two groups, namely, domestic and international. On the basis of the panel data of the 17 regions, we construct the following measurement models to explore the effects of air (environment) quality and other government policies on tourism:

$$
V_{\text {sit }}=\beta_{0}+\beta_{1} E_{i t}+\alpha G_{i t}+\gamma_{t}+\varepsilon_{i t}
$$

Where $V_{\text {sit }}$ is the total number of domestic $(s=0)$ or international $(s=1)$ tourists of the $i$-th province in the $t$-th year. $\beta_{0}$ is a constant term and $\beta_{1}$ is a regression coefficient of air (environment). $\alpha$ is a regression coefficient of policy variables. Moreover, $\gamma_{t}$ is a time-fixed effect, and $\varepsilon_{i t}$ is a disturbance term. $E_{i t}$ is an air (environment) explanatory variable that includes $\mathrm{CO}_{2}$ emission and PM2.5 average concentration. Further, $G_{i t}$ refers to policy variables such as urbanization, marketization, foreign trade, highway mileage, and railway mileage.

\subsection{Data, Variables, and Descriptive Statistics}

This study focuses on the impact of air (environment) quality and other government policies on visitors and explores the differential impact of these factors or policies on domestic and international visitors in detail. Table 1 provides the detailed variable settings.

Table 1. Main variables and calculation methods.

\begin{tabular}{lll}
\hline Variables & Variable Connotation & Calculation Methods \\
\hline $\ln \mathrm{DT}$ & Domestic tourists. & Domestic tourists take logarithm \\
$\ln \mathrm{TT}$ & International tourists. & International tourists take logarithm \\
$\operatorname{lnCO} 2$ & Carbon dioxide emissions & Carbon dioxide emissions take logarithm \\
$\ln \mathrm{PM}$ & PM 2.5 average concentration & PM 2.5 average concentration take logarithm \\
$\operatorname{lnUrb}$ & urbanization level & urbanization level take logarithm \\
$\operatorname{lnMark}$ & marketization index & marketization index take logarithm \\
$\operatorname{lnFT}$ & foreign trade & foreign trade take logarithm \\
$\ln \mathrm{RW}$ & railway mileage & railway mileage take logarithm \\
$\ln \mathrm{HW}$ & highway mileage & highway mileage take logarithm \\
\hline
\end{tabular}

Dependent variable. This study uses the number of tourists to measure the level of regional tourism development and is divided into domestic tourists and international visitors. This distinction helps in better understanding how regional government policies affect domestic and foreign tourists. We argue that domestic and foreign tourists may have different behavioral preferences or responses to tourism. In this study, the number of domestic tourists is denoted as $\log \ln \mathrm{DT}$ and the $\log$ for international 
tourists is denoted as $\log \ln I \mathrm{~T}$ as explanatory variables. All data are derived from the China Tourism Statistics Yearbook.

Independent variable (environment). We measure air (environment) quality by $\mathrm{CO}_{2}$ emissions and PM 2.5 concentrations. The higher the value of these two indicators, the worse the air (environment) quality. In the model, we use logarithm $l n \mathrm{CO}_{2}$ to represent $\mathrm{CO}_{2}$ emissions. The data on $\mathrm{CO}_{2}$ emissions are derived from China Emission Accounts and Datasets. In addition, we use the logarithm lnPM to represent PM 2.5 concentration, which is derived from the Columbia University Socioeconomic Data and Applications Center [42].

Other independent variables (policies). We examine the impact of other factors on tourism.

Urbanization. The level of urbanization has a positive impact on the economic development of China. This study uses the proportion of the non-agricultural population to measure the level of urbanization. We use logarithm $\ln U r b$ to represent the level of urbanization. The data on urbanization level are derived the China Statistical Yearbook.

Marketization. Marketization can bring increased vitality to tourism and improve the efficiency of the industry. In the model, we use the logarithm lnMark to represent the level of marketization. These data are derived from Wang et al.'s (2016) marketization index report, namely, China's Provincial Marketization Index Report (2016) [43].

Foreign trade. This study believes that foreign trade emphasizes the economic exchanges between domestic and foreign companies. This type of economic exchange is conducive to promoting cooperation among parties in various fields, such as encouraging foreign tourists to travel to China. In this study, the total import and export volumes are used as a measure of total foreign trade. The model uses logarithm $\operatorname{lnFT}$ to represent total foreign trade. The data were derived from the China Statistical Yearbook.

Transportation mileage. Transportation is an important factor in the consideration of traveling because convenience during transportation is an important indicator of the level of development of tourism. Therefore, this study incorporates traffic into the model to test its impact on tourism. However, according to the actual situation, the National Bureau of Statistics data does not have specific statistics on the flight route mileage; hence, we do not include the flight mileage into the transportation mileage. The measurement of transportation mileage includes two aspects, namely, highway and railway mileage. In the model, we use the logarithms $\operatorname{lnHW}$ and $\ln R W$ to represent highway and railway mileages, respectively. Transportation mileage data are derived from the China Regional Economic Statistics Yearbook.

To understand the characteristics of the data, we conduct a descriptive statistical analysis of the various characteristics of the main variables of this study. The sample data for this paper include observations from 2005 to 2015 in 17 western provinces of China, with a total sample size of 187 . The descriptive statistics in Table 2 shows a large variation between the observed values of the variables, which provides the possibility of the following econometric estimation.

Table 2. Descriptive statistics of variables.

\begin{tabular}{cccccc}
\hline Variable & Mean & Std. Dev. & Min & Max & Observations \\
\hline $\ln$ DT & 9.278493 & 1.020568 & 6.45047 & 10.97679 & $n=187$ \\
$\operatorname{lnIT}$ & 4.555244 & 1.160149 & 1.098612 & 6.345636 & $n=187$ \\
$\operatorname{lnCO} 2$ & 5.385871 & 0.637381 & 2.99072 & 6.432297 & $n=187$ \\
$\operatorname{lnPM}$ & 3.100933 & 0.661995 & 1.568501 & 4.113909 & $n=187$ \\
$\operatorname{lnUrb}$ & 3.789561 & 0.246742 & 3.030823 & 4.209903 & $n=187$ \\
$\operatorname{lnMark}$ & 1.65028 & 0.258334 & 0.928219 & 2.075685 & $n=187$ \\
$\operatorname{lnFT}$ & 14.11975 & 1.083563 & 10.62936 & 16.25331 & $n=187$ \\
$\ln \mathrm{RW}$ & 8.169016 & 0.391511 & 6.995766 & 9.400465 & $n=187$ \\
$\ln \mathrm{HW}$ & 11.83169 & 0.440624 & 10.29958 & 12.66217 & $n=187$ \\
\hline
\end{tabular}


Figure 1 illustrates the regional distribution of all variables. Domestic tourists are mainly concentrated in the central part of China, especially in the Yangtze River, whereas international tourists are distributed in various parts of China and are relatively scattered. The carbon dioxide emissions of the country mainly occur in the northeast, whereas high PM 2.5 concentrations mainly occur in the eastern and central regions. The marketization index of China mainly ranges between 4 and 8 , and the marketization level in the central and eastern regions is relatively high, followed by the northern and southern regions. The level of foreign trade in the eastern region is relatively high, with little differences in other regions. In terms of internal transportation, the mileage of various expressways in the country is relatively high. That is, the expressway has been well developed, and the total mileage of most of the shares has reached more than 100,000 km. The average mileage of each railway mainly spans between 1500 and $4500 \mathrm{~km}$, and the level of each development is even. The current level of urbanization in China generally ranges between $40 \%$ and $60 \%$, with a relatively large space for the improvement of the development of urbanization.

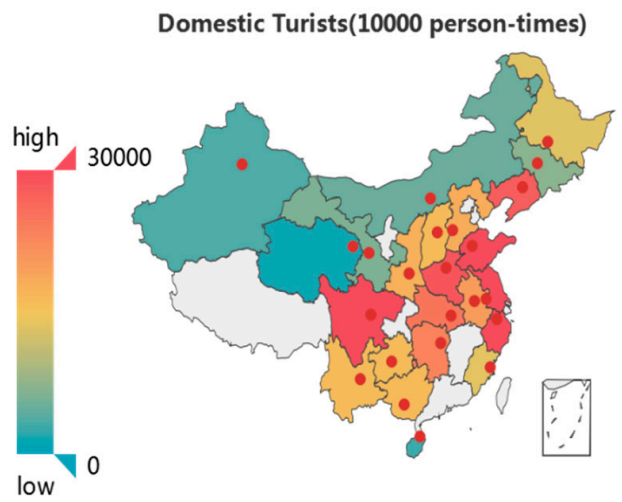

Carbon Dioxide Emissions(Million Tons)

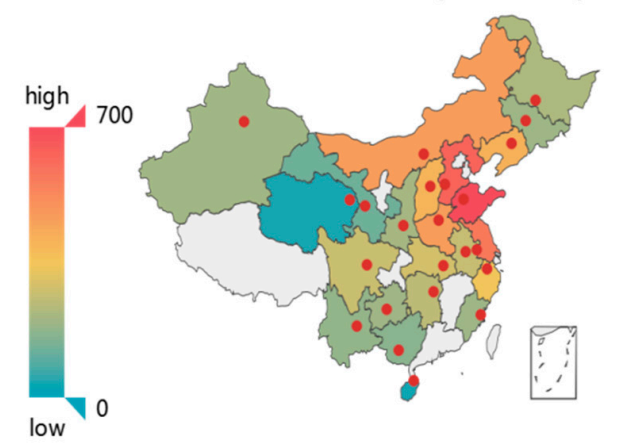

Marketization Index

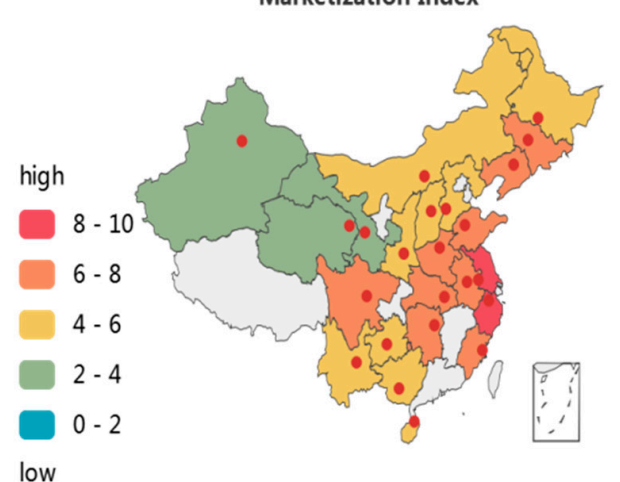

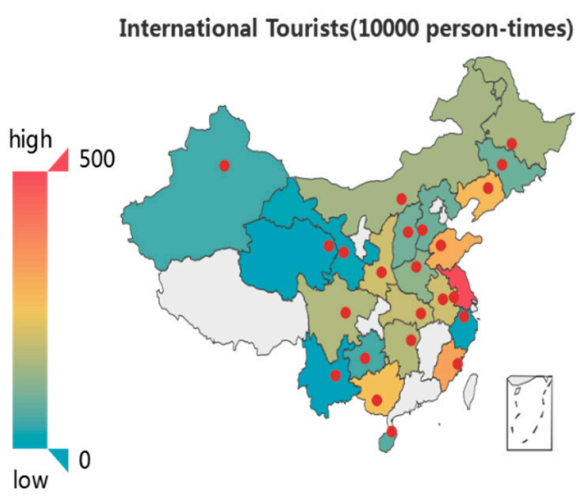

PM2.5 Concentration Value $(\mu \mathrm{g} / \mathrm{m} 3)$
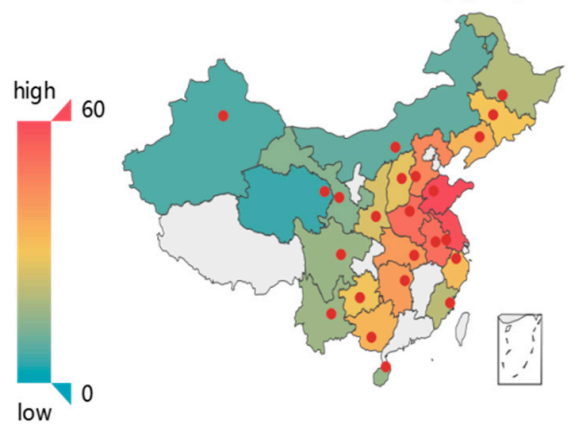

Foreign Trade(Million Dollar)

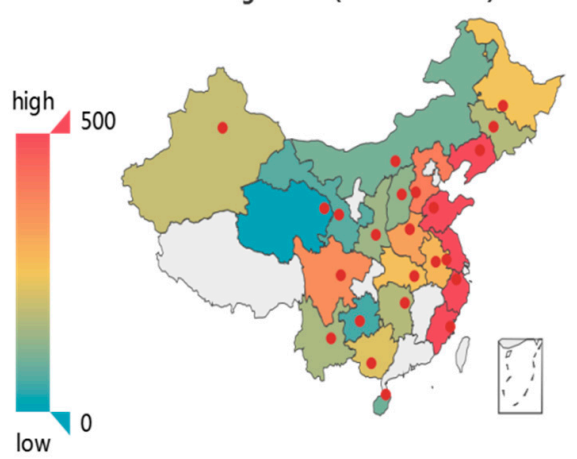

Figure 1. Cont. 


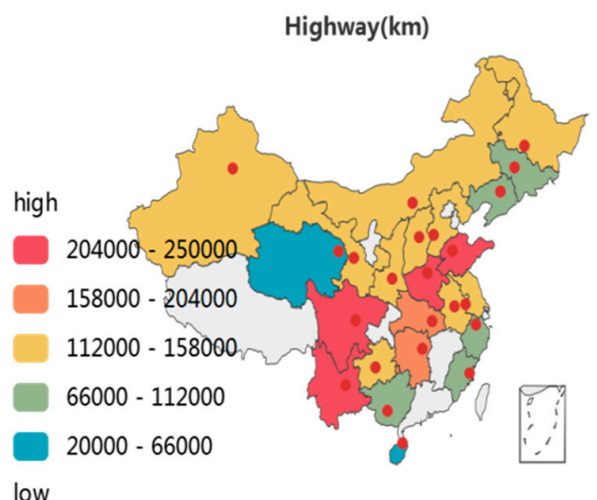

Urbanization Level(\%)

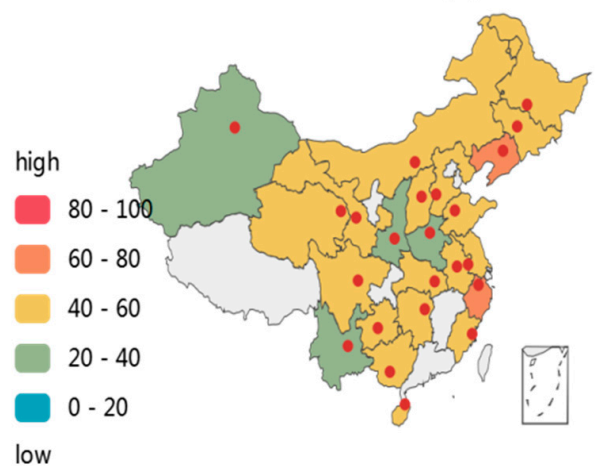

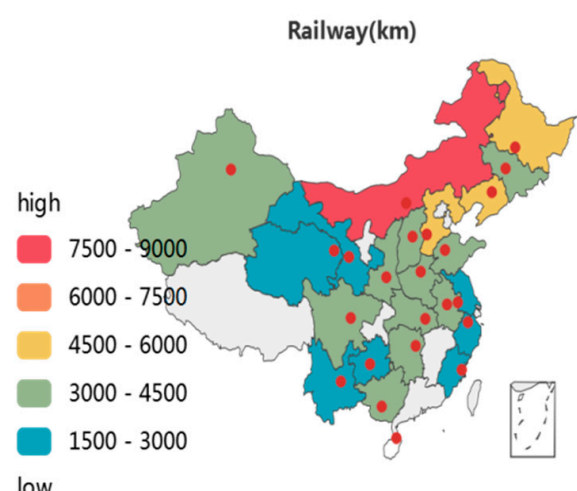

low

Figure 1. Spatial distribution of indicators.

In addition, from the perspective of growth rate trends (Figure 2), domestic tourists have displayed a positive growth trend, whereas the opposite is true for foreign tourists, which is basically a horizontal stable trend. In terms of air (environment), carbon dioxide emissions have decreased since 2011, and PM 2.5 concentrations generally have a downward trend. However, the decline is relative with significant increases in 2013 and 2015. We also depict a trend chart of tourism development in Figure 3. Figure $3 a, b$ depicts that the vertical axis is the number of tourists. Moreover, the figures affirm that the number of tourists in almost all provinces shows a steady development trend regardless of the number of domestic tourists or the number of international tourists. However, we are unable to include the trend graphs of other indicators for brevity.

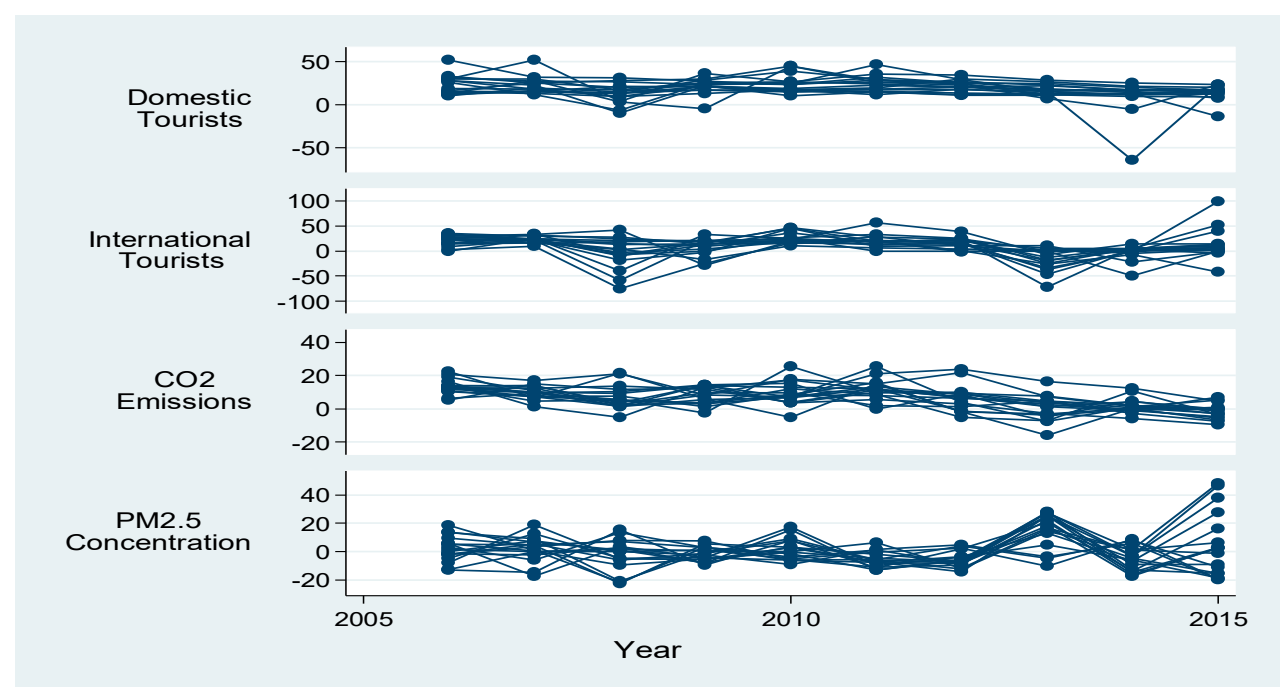

Figure 2. Change in the growth rate of each variable. 


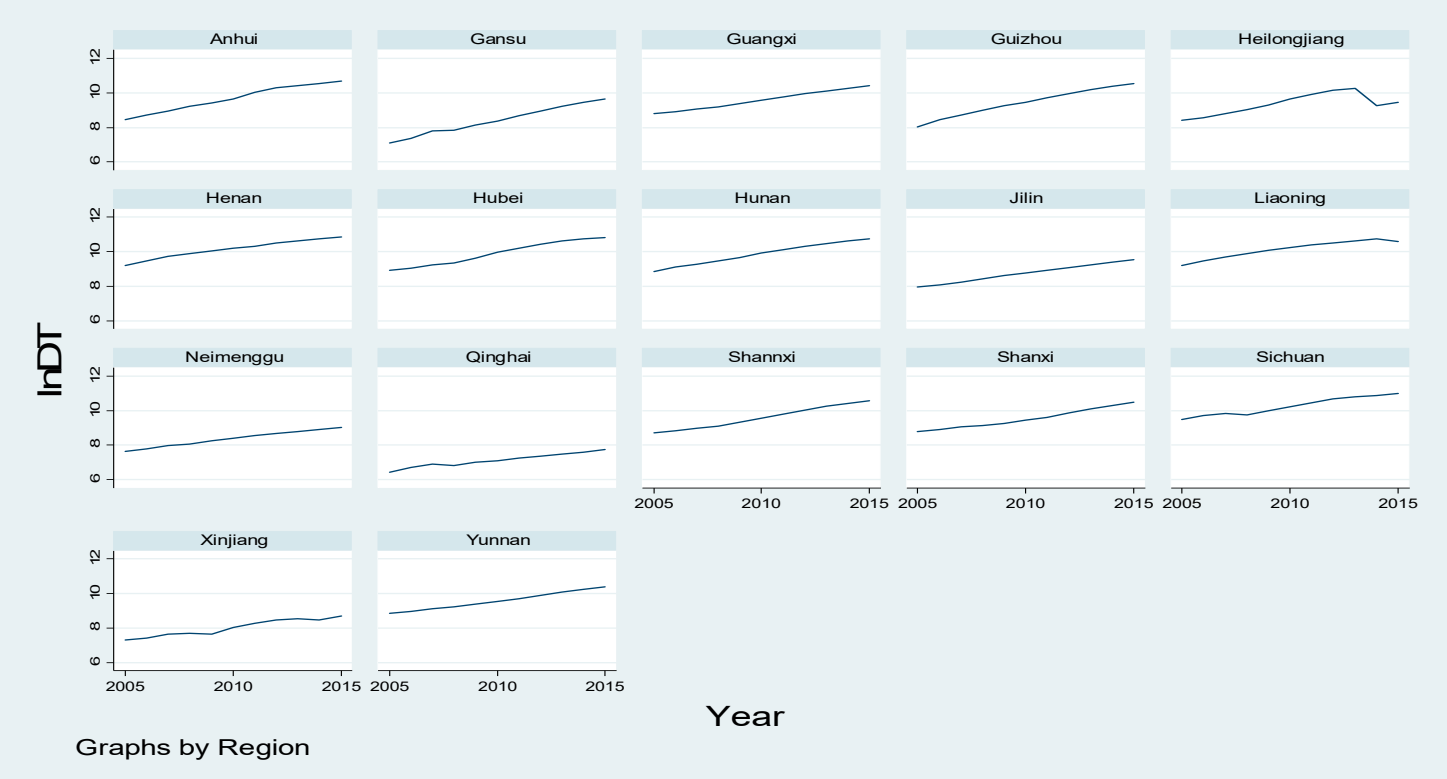

(a)

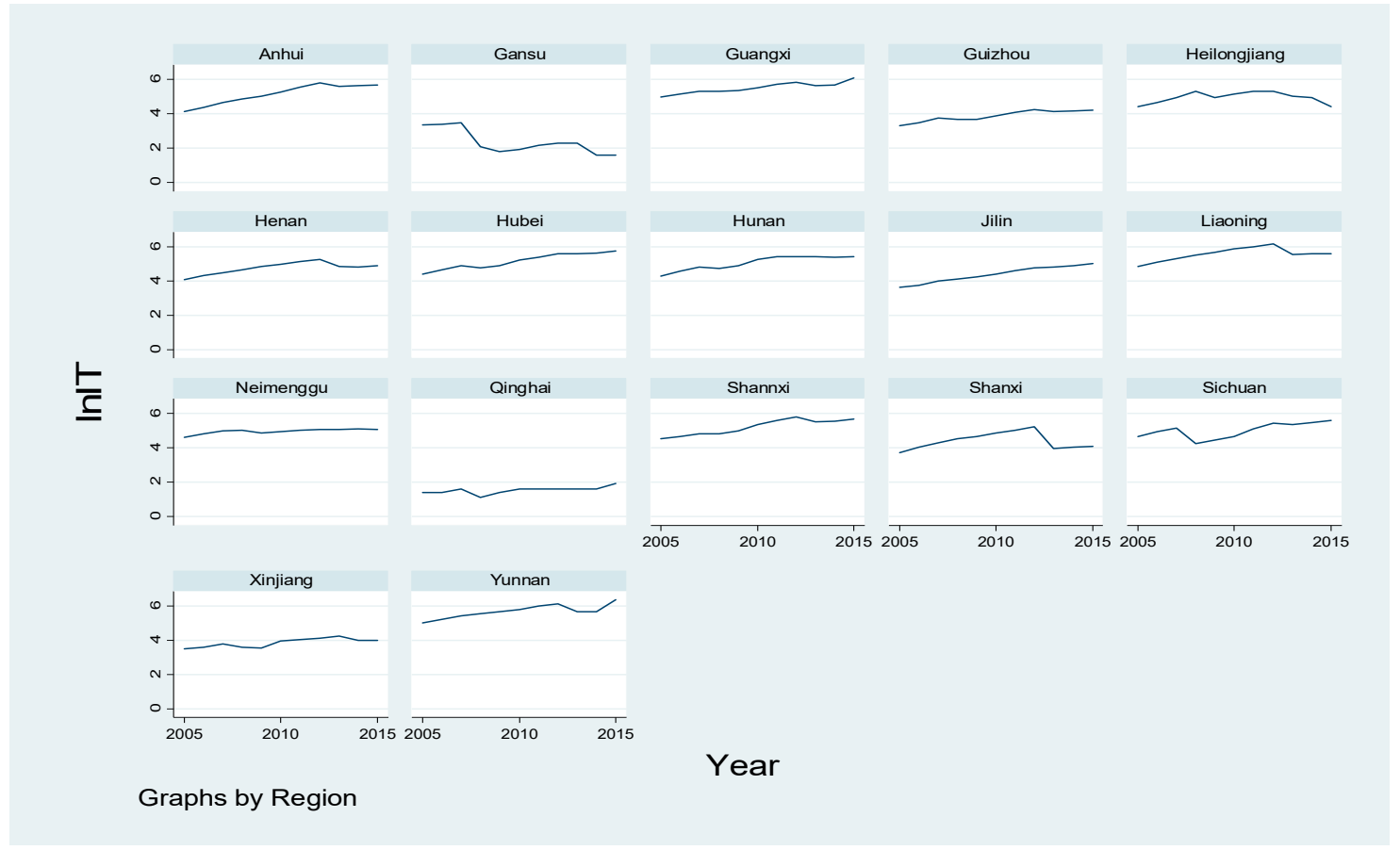

(b)

Figure 3. (a) Tourism development trend; (b) tourism development trend.

The scatter plot in Figure 4 reveals that $\mathrm{CO}_{2} / \mathrm{PM} 2.5$ and domestic/international tourists show an evident linear correlation. Support for statistical data was provided by the linear regression analysis in the next step of the study. We omit the individual relationship between other indicators and tourism for brevity. However, we will conduct an in-depth discussion in the following model test. 

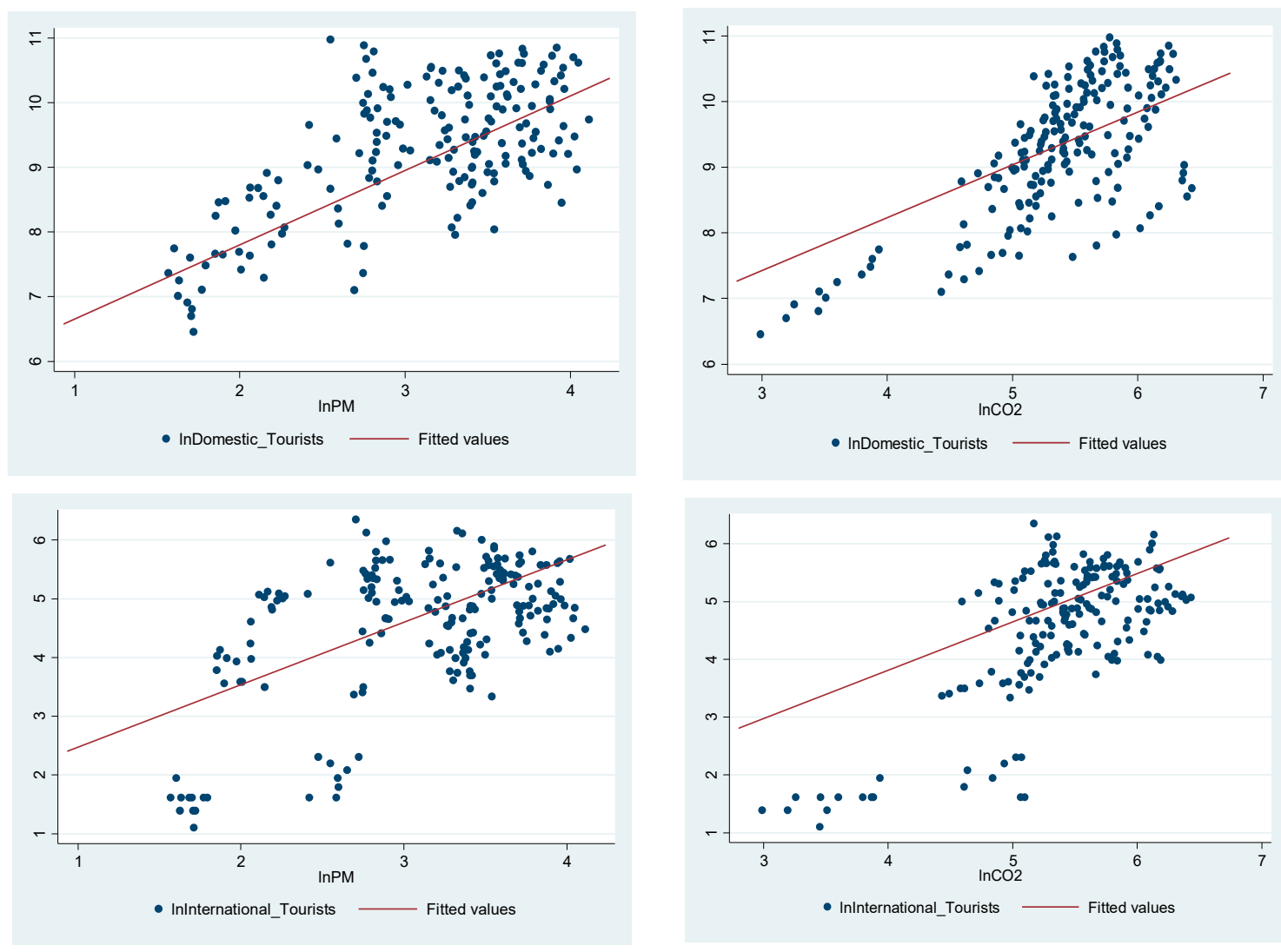

Figure 4. Linear fit of each variable.

\section{Empirical Analysis}

We analyze data from 17 of China's underdeveloped regions. The panel data model is typically estimated using a random or fixed effects model. The difference between the two methods is that the random effects model is relatively more efficient but requires that exogenous variables be unrelated to individual effects. However, although the fixed effects model has no requirements between exogenous variables and individual effects, it consumes more degrees of freedom; hence, both have advantages and disadvantages [44]. To this end, the study selects between the two estimation methods using the Hausman test. Through the model selection test, we corroborate that the random effects model (LM test: chibar2 $(01)=375.02, p=0.0000)$ and fixed effect model (F test that all $u \_i=0: \mathrm{F}(16,154)=49.63$, Prob $>F=0.0000$ ) are superior to the mixed effects model for the domestic tourist group. Thereafter, we perform the Hausmantest (chi2 $(16)=83.03, p=0.000$ ) on the random and fixed effect models. Results affirm that the fixed effects model is better than the random effects model. Therefore, we mainly adopt the test results of the fixed effects model for the domestic group. For the international visitor group, the random effects model (LM test: chibar2(01) $=395.51, p=0.0000$ ) and fixed effects model ( $F$ test that all $u \_i=0: F(16,153)=30.10$, Prob $\left.>F=0.0000\right)$ are superior to the mixed effects model. Thereafter, we perform the Hausmantest $(\operatorname{chi} 2(17)=9.00, p=0.9403)$ on the random and fixed effects models. Results reveal that the random effects model is better than the fixed effects model. Therefore, we adopt the test results of the random effects model for the international group.

When using the above variables for estimation, all variables take the natural logarithm, such that the estimated coefficient of the variable can also be regarded as the elastic coefficient. The estimation results affirm that our previous theoretical judgments are supported by the data in general. For domestic tourism, we adopt a fixed effects estimate because the Hausman test rejects the random effects model. For international tourism, we adopt the estimation of random effects because the Hausman test cannot reject the random effects model. Table 3 illustrates the following estimation results. First, the impact of carbon dioxide $\left(\mathrm{CO}_{2}\right)$ on tourism is negative $(\beta=-0.234, \mathrm{~ns})$ for domestic tourism, 
but the significance level has not passed the test. The PM 2.5 concentration $(\beta=-0.383, p<0.01)$ significantly negatively affects domestic tourism. Urbanization $(\beta=0.780, p<0.05)$ significantly promotes domestic tourism, which indicates that the level of urbanization is effective in promoting the travel of domestic residents. The level of marketization $(\beta=0.334, p<0.05)$ also has a positive impact on domestic tourism. In terms of transportation, highway construction $(\beta=0.492, p<0.01)$ has a significant effect on domestic tourism, and the impact of the railway on domestic travel is positive ( $\beta=0.204, \mathrm{~ns}$ ), but non-significant. This finding implies that the manner in which domestic residents travel to domestic tourism may be biased by road transportation (such as self-driving tour).Second, no significant effect was observed for carbon dioxide ( $\beta=-0.156, \mathrm{~ns})$ or PM 2.5 ( $\beta=0.289$, ns) on international tourists. However, urbanization $(\beta=-1.664, p<0.01)$ displays a significant negative impact on international tourism, which indicates that international travelers are likely to travel to less urbanized areas due to the primitive and natural scenery. The level of marketization $(\beta=0.627, p<0.05)$ also has a positive impact on international tourists. In terms of transportation, findings suggest that the impact of expressway construction $(\beta=-0.222, \mathrm{~ns})$ on international tourism is non-significant and that the impact of railways on international tourists is positive $(\beta=0.775, p<0.01)$. This result confirms that the railways of China, especially the development of its high-speed railways in recent years, have made remarkable achievements internationally. International tourists are further inclined to ride and experience the high-speed rail travel of the country. Furthermore, the level of foreign trade ( $\beta=0.775, p<0.01)$ also has a significant positive impact on international tourism. As such, foreign trade promotes domestic and foreign exchanges and attracts more international travelers to China.

Table 3. Estimation results of econometric models.

\begin{tabular}{|c|c|c|c|c|}
\hline \multirow[b]{2}{*}{ IV } & \multicolumn{2}{|c|}{ DV: $\operatorname{lnDT}$} & \multicolumn{2}{|c|}{ DV: $\ln I T$} \\
\hline & $\begin{array}{c}\text { Random Effects } \\
\text { Model }\end{array}$ & $\begin{array}{c}\text { Fixed Effects } \\
\text { Model }\end{array}$ & $\begin{array}{c}\text { Random Effects } \\
\text { Model }\end{array}$ & $\begin{array}{c}\text { Fixed Effects } \\
\text { Model }\end{array}$ \\
\hline $\operatorname{lnCO} 2$ & $\begin{array}{l}0.0130 \\
(0.14)\end{array}$ & $\begin{array}{l}-0.234 \\
(0.14)\end{array}$ & $\begin{array}{c}-0.156 \\
(0.23)\end{array}$ & $\begin{array}{c}-0.367 \\
(0.27)\end{array}$ \\
\hline $\ln P M$ & $\begin{array}{l}0.181 \\
(0.12)\end{array}$ & $\begin{array}{c}-0.383^{* * *} \\
(0.14)\end{array}$ & $\begin{array}{l}0.289 \\
(0.19)\end{array}$ & $\begin{array}{l}0.185 \\
(0.27)\end{array}$ \\
\hline lnMark & $\begin{array}{c}0.532 * * * \\
(0.16)\end{array}$ & $\begin{array}{c}0.334^{* *} \\
(0.15)\end{array}$ & $\begin{array}{c}0.627^{* *} \\
(0.28)\end{array}$ & $\begin{array}{l}0.460 \\
(0.30)\end{array}$ \\
\hline $\operatorname{lnFT}$ & & & $\begin{array}{c}0.687^{* * *} \\
(0.11)\end{array}$ & $\begin{array}{c}0.668^{* * *} \\
(0.13)\end{array}$ \\
\hline $\ln U r b$ & $\begin{array}{c}0.662^{* *} \\
(0.28)\end{array}$ & $\begin{array}{c}0.780 * * \\
(0.34)\end{array}$ & $\begin{array}{c}-1.664^{* * *} \\
(0.48)\end{array}$ & $\begin{array}{c}-1.853 * * * \\
(0.69)\end{array}$ \\
\hline $\ln R W$ & $\begin{array}{l}0.144 \\
(0.18)\end{array}$ & $\begin{array}{l}0.204 \\
(0.17)\end{array}$ & $\begin{array}{c}0.775^{* * *} \\
(0.29)\end{array}$ & $\begin{array}{c}0.746^{* *} \\
(0.33)\end{array}$ \\
\hline $\operatorname{lnHW}$ & $\begin{array}{c}0.751 * * * \\
(0.14)\end{array}$ & $\begin{array}{c}0.492^{* * *} \\
(0.14)\end{array}$ & $\begin{array}{c}-0.222 \\
(0.24)\end{array}$ & $\begin{array}{c}-0.429 \\
(0.28)\end{array}$ \\
\hline $\begin{array}{l}\text { Time effect } \\
\text { cons }\end{array}$ & $\begin{array}{c}\text { controlled } \\
-5.084^{* *} \\
(2.26)\end{array}$ & $\begin{array}{c}\text { controlled } \\
0.205 \\
(2.61)\end{array}$ & $\begin{array}{c}\text { controlled } \\
-3.819 \\
(3.64)\end{array}$ & $\begin{array}{c}\text { controlled } \\
1.297 \\
(5.10)\end{array}$ \\
\hline Hausman test $(p)$ & \multicolumn{2}{|c|}{$\operatorname{chi} 2(16)=83.03(0.000)$} & \multicolumn{2}{|c|}{ chi2 $(17)=9.00(0.9403)$} \\
\hline $\mathrm{N}$ & 187 & 187 & 187 & 187 \\
\hline r2 & & 0.943 & & 0.554 \\
\hline $\mathrm{r} 2 \mathrm{a}$ & & 0.931 & & 0.457 \\
\hline $\mathrm{F}$ & & 158.308 & & 11.159 \\
\hline Wald & $\operatorname{chi} 2(16)=1974.40$ & & $\operatorname{chi} 2(17)=231.72$ & \\
\hline
\end{tabular}

We summarize the results of the hypothesis testing to help us more intuitively compare the differences in the impact of various factors on domestic and international visitors (see Table 4). We prove that government policies and basic transportation construction play a positive role in promoting domestic and international tourism for economically underdeveloped provinces. In sum, the impact of carbon dioxide on tourism is non-significant among the air (environment) quality 
factors whether for domestic or international tourists. However, PM 2.5 concentration has varied influences on domestic and international tourists. Domestic tourists are sensitive to changes in PM 2.5 concentration, whereas international tourists are less sensitive. Particularly, the PM 2.5 indicator has a strong inhibitory effect on the travel of domestic tourists. In addition, although the impact of $\mathrm{CO}_{2}$ is non-significant, it remains negative. The reason for this result may be that the effect of PM 2.5 on air is intuitive. Thus, a high concentration of PM 2.5 indicates poor air quality. People can perceive the negative air quality through personal experience or observation, thereby directly affecting the travel plans of people. Although $\mathrm{CO}_{2}$ negatively influences the air and environment, this effect is not intuitive. Therefore, materializing the impact of $\mathrm{CO}_{2}$ on the air or environment through personal experience or observation is difficult. Hence, the impact of $\mathrm{CO}_{2}$ emissions on tourists is relatively limited. Surprisingly, the simultaneous impact of $\mathrm{CO}_{2}$ emissions and PM 2.5 concentrations on international visitors is non-significant. The reason for this finding may be that international passengers do not observe the air (environment) situation of China or have little or no information about this condition before traveling to the country. In other cases, they may not pay attention to this information. Therefore, the impact of $\mathrm{CO}_{2}$ emissions or PM 2.5 concentration on international tourists is non-significant or fails to be an important consideration before tourists decide to travel to China. Another possible explanation is that the subjects we study in this paper are mainly the provinces with less developed economies in Western China. The air (environment) quality of these areas is not very bad compared with other regions; Figure 1 exhibits such differences. Therefore, whether it is from the air (environment) quality perceived by tourists or from the perspective of data model analysis, the overall air (environment) quality has no significant impact on tourists. Of course, this does not mean that the quality of air (environment) has little effect on tourism, but it just infers that the air (environment) quality of these areas is well controlled and that no serious impact on tourism development has emerged. The impact of marketization on domestic and international tourism is positive and significant, which also reveals that the degree of the openness of the government to the market has a positive impact on tourism and may even affect the entire economy. In addition, the impact of urbanization on domestic and international tourists differs. Specific performance suggests that urbanization has a significant positive impact on domestic tourists, whereas this impact is negative on international tourists. That is, the higher the level of urbanization, the weaker the ability to attract international tourists. In addition, foreign trade can further promote international travelers to travel to China. The impact of traffic construction on domestic and international tourists also differs. Specifically, the increase in highway mileage has a positive effect on the promotion of domestic tourism, whereas this impact is non-significant on international tourists. Conversely, the increase in railway mileage has no significant impact on domestic tourists, whereas this impact is positive on international tourists. Finally, the increase in railway mileage has a positive effect on the impact of international tourism.

Table 4. Summary of Research Hypothesis Test Results.

\begin{tabular}{|c|c|c|c|}
\hline \multirow{2}{*}{ Hypothesis Description } & \multirow{2}{*}{ Independents } & \multicolumn{2}{|c|}{ Comparison } \\
\hline & & Domestic Set & International Se \\
\hline \multirow{2}{*}{$\begin{array}{l}\text { Air (environment) pollution will have a negative impact on domestic } \\
\text { and international visitors. }\end{array}$} & $\mathrm{CO}_{2}$ & Not supported & Not supported \\
\hline & PM 2.5 & Supported $(-)$ & Not supported \\
\hline $\begin{array}{l}\text { Urbanization has a positive impact on domestic tourism but a } \\
\text { negative impact on international tourism. }\end{array}$ & Urbanization & Supported (+) & Supported $(-)$ \\
\hline Marketization promoting domestic and international tourism. & Marketization & Supported (+) & Supported (+) \\
\hline Foreign trade has a positive impact on international tourists. & Foreign trade & - & Supported \\
\hline \multirow{2}{*}{$\begin{array}{l}\text { Transportation can promote the development of tourism. In } \\
\text { particular, compared with railways, highways have a greater impact } \\
\text { on domestic tourists; compared with highways, railways have a } \\
\text { greater impact on international tourists. }\end{array}$} & Highway & Supported (+) & Not supported \\
\hline & Railway & Not supported & Supported (+) \\
\hline
\end{tabular}

Note: The symbols in parentheses represent the potency of the influence. For example, $(-)$ represents a negative influence, $(+)$ represents a positive influence. 


\section{Implications and Limitations}

The results provide certain considerations and challenges for the sustainable development of tourism in underdeveloped areas in China. First, pursuing tourism development while paying attention to the negative impact of air (environment) quality should be prioritized. Particularly, we emphasize the notable impact of the PM 2.5 concentration on tourism because its impact on tourists is direct. Although, from the statistical point of view (Figure 2), the PM 2.5 concentration of these parts shows a downward trend annually. However, this decline is still relatively slow. Therefore, the government should continue or increase environmental protection policies, such as energy conservation and emission reduction. Otherwise, the sustainable development of tourism will become a big challenge. Second, the local government's economic policies have played an extremely positive role in promoting the development of tourism. Local governments should be further open to economic development. The analysis results reveal that local governments should implement open economic policies. That is, marketization has a positive impact on domestic and foreign tourists. In addition, the increase in foreign trade plays a positive role in promoting tourism. Specifically, we add foreign trade variables to the international tourism model and corroborate that its impact on the travel of international tourists to China remains largely significant. Therefore, in addition to the open domestic economic development policy for local governments, the more open foreign trade has played a positive role in promoting international tourists. After the reform and opening up, economic openness and non-nationalization have become the trends of the times. As such, reducing participation in economic activities and mobilizing the power of the market to bring vitality to the tourism market are necessary for local governments. Third, urban construction and basic transportation construction policies also have a positive impact on tourism. The improvement of the level of urbanization is conducive to promoting the income level of the entire population and narrowing the income gap between urban and rural areas. Currently, the urbanization level of China ranges between $40 \%$ and $60 \%$ (Figure 1). Hence, the level of urbanization still has a relatively large room for improvement. For the tourism industry, rural residents with increasing incomes are an attractive market. In addition, local governments should also consider the impact of urbanization on international tourists. For regions that rely on natural scenery as their main destination, maintaining a comprehensive and original social outlook may be attractive. In this respect, excessive urbanization may weaken the attractiveness of local attractions to international tourists.

One limitation of this study is that our results are based on the data analysis of Chinese single subjects. The results may only adapt to the Chinese context, but we also believe that some developing countries similar to China can learn from the experience of China and the results of this study to adjust their tourism development strategies. Future researchers can incorporate the situation of each country into a comparative model from a more macro perspective and explore whether the development of other countries is consistent with the results of this study or have different or even opposite trends. In addition, this study only analyzes the differences between domestic and international tourists through macro data. We cannot fundamentally understand why they have this difference. For instance, knowing precisely the difference in the impact of air (environment) quality factors on domestic and international visitors is difficult. We only know that such a difference exists. Therefore, future research can further explore the mechanisms behind these differences by combining some micro data such as interviews and questionnaires. In short, distinguishing domestic tourists from international tourists is reasonable because they should have different responses to tourism policies and corporate marketing strategies. Therefore, future research can comprehensively compare and analyze the differences between the two types of tourists from different angles, not just the factors mentioned in this paper.

Author Contributions: J.L. performed the conceptualization for the first manuscript; H.P. was the major writer of the original draft and performed the review \& editing of the manuscript; S.Z. performed data collection.

Funding: This work was supported by the National Natural Science Foundation of China (Grant No.91746206), the Key Research Institute of Philosophies and Social Sciences in Guangxi Universities (Grant No.17YB001), and the Scientific Research Foundation of Guilin University of Technology (Grant No. GLUTQD2018054). 
Conflicts of Interest: The authors declare no conflict of interest.

\section{References}

1. Ahmad, F.; Draz, M.U.; Su, L.; Ozturk, I.; Rauf, A. Tourism and Environmental Pollution: Evidence from the One Belt One Road Provinces of Western China. Sustainability 2018, 10, 3520. [CrossRef]

2. Wu, M.-Y.; Pearce, P.L. Tourists to Lhasa, Tibet: How Local Youth Classify, Understand and Respond to Different Types of Travelers. Asia Pac. J. Tour. Res. 2013, 18, 549-572. [CrossRef]

3. Kadiyali, V.; Kosová, R. Inter-industry employment spillovers from tourism inflows. Reg. Sci. Urban Econ. 2013, 43, 272-281. [CrossRef]

4. Njoya, E.T.; Seetaram, N. Tourism Contribution to Poverty Alleviation in Kenya: A Dynamic Computable General Equilibrium Analysis. J. Travel Res. 2018, 57, 513-524. [CrossRef] [PubMed]

5. Crouch, G.I.; Del Chiappa, G.; Perdue, R.R. International convention tourism: A choice modelling experiment of host city competition. Tour. Manag. 2019, 71, 530-542. [CrossRef]

6. Andersson, T.D.; Getz, D. Tourism as a mixed industry: Differences between private, public and not-for-profit festivals. Tour. Manag. 2009, 30, 847-856. [CrossRef]

7. Aratuo, D.N.; Etienne, X.L. Industry level analysis of tourism-economic growth in the United States. Tour. Manag. 2019, 70, 333-340. [CrossRef]

8. Cohen, E. Globalization, global crises and tourism. Tour. Recreat. Res. 2012, 37, 103-111. [CrossRef]

9. Frossard, M.S.; Fraga, C. Tourism, railway and advertising: the construction of feelings and meanings in the posters of railroads in the United Kingdom (1890-1970). Anais Brasileiros De Estudos Turisticos-AbeT 2018, $8,43-55$.

10. Liu, Y.; Li, Y.; Parkpian, P. Inbound tourism in Thailand: Market form and scale differentiation in ASEAN source countries. Tour. Manag. 2018, 64, 22-36. [CrossRef]

11. Luo, J.M.; Qiu, H.; Goh, C.; Wang, D. An Analysis of TOURISM Development in China From Urbanization Perspective. J. Qual. Assur. Hosp. Tour. 2016, 17, 24-44. [CrossRef]

12. Mondal, M.; Dandapath, P.K. Urbanization and its impact on coastal eco-tourism in West Bengal. Int. J. Sci. Res. 2013, 2, 114-119.

13. Yorucu, V. Growth impact of $\mathrm{CO}_{2}$ emissions caused by tourist arrivals in Turkey An econometric approach. Int. J. Clim. Chang. Strateg. Manag. 2016, 8, 19-37. [CrossRef]

14. Zhou, B.; Qu, H.; Du, X.; Yang, B.; Liu, F. Air quality and inbound tourism in China. Tour. Anal. 2018, 23, 159-164. [CrossRef]

15. Becken, S.; Jin, X.; Zhang, C.; Gao, J. Urban air pollution in China: Destination image and risk perceptions. J. Sustain. Tour. 2017, 25, 130-147. [CrossRef]

16. Luo, J.M.; Qiu, H.; Lam, C.F. Urbanization impacts on regional tourism development: A case study in China. Curr. Issues Tour. 2016, 19, 282-295. [CrossRef]

17. Paramati, S.R.; Alam, M.S.; Chen, C.-F. The Effects of Tourism on Economic Growth and $\mathrm{CO}_{2}$ Emissions: A Comparison between Developed and Developing Economies. J. Travel Res. 2017, 56, 712-724. [CrossRef]

18. Raza, S.A.; Sharif, A.; Wong, W.K.; Abd Karim, M.Z. Tourism development and environmental degradation in the United States: Evidence from wavelet-based analysis. Curr. Issues Tour. 2017, 20, 1768-1790. [CrossRef]

19. Shakouri, B.; Yazdi, S.K.; Ghorchebigi, E. Does tourism development promote $\mathrm{CO}_{2}$ emissions? Anatolia-Int. J. Tour. Hosp. Res. 2017, 28, 444-452. [CrossRef]

20. Wang, L.; Fang, B.; Law, R. Effect of air quality in the place of origin on outbound tourism demand: Disposable income as a moderator. Tour. Manag. 2018, 68, 152-161. [CrossRef]

21. Wang, M.-C.; Wang, C.-S. Tourism, the environment, and energy policies. Tour. Econ. 2018, 24, 821-838. [CrossRef]

22. Zaman, K.; Shahbaz, M.; Loganathan, N.; Raza, S.A. Tourism development, energy consumption and Environmental Kuznets Curve: Trivariate analysis in the panel of developed and developing countries. Tour. Manag. 2016, 54, 275-283. [CrossRef]

23. Chen, L.; Thapa, B.; Yan, W. The Relationship between Tourism, Carbon Dioxide Emissions, and Economic Growth in the Yangtze River Delta, China. Sustainability 2018, 10, 2118. [CrossRef]

24. Mullins, P. Tourism Urbanization. Int. J. Urban Reg. Res. 1991, 15, 326-342. [CrossRef] 
25. Palamalai, S.; Kalaivani, M. Tourism Expansion, Urbanization and Economic Growth in India: An Empirical Analysis. IUP J. Bus. Strategy 2016, 13, 135-151.

26. Shinde, K.A. Planning for urbanization in religious tourism destinations: Insights from Shirdi, India. Plan. Pract. Res. 2017, 32, 132-151. [CrossRef]

27. Ashworth, G.; Page, S.J. Urban tourism research: Recent progress and current paradoxes. Tour. Manag. 2011, 32, 1-15. [CrossRef]

28. Naidu, S. Exploring the dynamic effects of urbanization and real effective exchange rate on tourism output of singapore. Tour. Anal. 2017, 22, 185-200. [CrossRef]

29. Munari, A.B.; de Assuncao, V.K.; de Menezes, C.T. Socio-Environmental Problems Arising from Urbanization and Tourism: Lagoa das Capivaras, Garopaba (SC), Brazil Case Study. Desenvolv. E Meio Ambiente 2018, 44, 242-266. [CrossRef]

30. Cuadrado-Ciuraneta, S.; Durà-Guimerà, A.; Salvati, L. Not only tourism: Unravelling suburbanization, second-home expansion and "rural" sprawl in Catalonia, Spain. Urban Geogr. 2017, 38, 66-89. [CrossRef]

31. Callon, M. Revisiting marketization: From interface-markets to market-agencements. Consum. Mark. Cult. 2016, 19, 17-37. [CrossRef]

32. Podedworna, H. Marketization of rural resources in Poland. Sociol. Rev. 2010, 2, 127-145.

33. Belk, R.W. Güliz Ger Problems of Marketization in Romania and Turkey. Res. Consum. Behav. 1994, 7, $123-155$.

34. Bianchi, R. The political economy of tourism development: A critical review. Ann. Tour. Res. 2018, 70, 88-102. [CrossRef]

35. Fletcher, R. Sustaining tourism, sustaining capitalism? The tourism industry's role in global capitalist expansion. Tour. Geogr. 2011, 13, 443-461. [CrossRef]

36. Yu, L. On Enhancing Tour. Manag. Quality in Scenic Spots. In Proceedings of the 2013 Fourth International Conference on Education and Sports Education (ESE 2013), Hong Kong, China, 11-12 April 2013; Volume 12, pp. 189-193.

37. Wang, C.; Dai, S.; Xu, H.; Li, X. The Impact of the Institutional Environment on the Geographic Diversification of Chinese Tourism Firms. J. China Tour. Res. 2018, 14, 334-353. [CrossRef]

38. Van Hoa, T.; Turner, L.; Vu, J. Economic impact of Chinese tourism on Australia: A new approach. Tour. Econ. 2018, 24, 677-689.

39. Tsui, W.H.K.; Balli, F.; Tan, D.T.W.; Lau, O.; Hasan, M. New Zealand business tourism: Exploring the impact of economic policy uncertainties. Tour. Econ. 2018, 24, 386-417. [CrossRef]

40. Quan, S.; Wang, N. Towards a structural model of the tourist experience: An illustration from food experiences in tourism. Tour. Manag. 2004, 25, 297-305. [CrossRef]

41. Chang, Y.; Yang, Y.; Dong, S. sustainability evaluation of high-speed railway (HSR) construction projects based on unascertained measure and analytic hierarchy process. Sustainability (Switzerland) 2018, 10, 408. [CrossRef]

42. van Donkelaar, A.; Martin, R. V.; Brauer, M.; Hsu, N.C.; Kahn, R.A.; Levy, R.C.; Lyapustin, A.; Sayer, A.M.; Winker, D.M. Global Estimates of Fine Particulate Matter using a Combined Geophysical-Statistical Method with Information from Satellites, Models, and Monitors. Environ. Sci. Technol. 2016, 50, 3762-3772. [CrossRef] [PubMed]

43. Wang, X.; Fan, G.; Yu, J. Marketization Index of China's Provinces: Neri Report 2016; Social Sciences Academic Press(China): Beijing, China, 2017.

44. Baltagi, B.H. Solutions to Problems Posed in Volume 20(1) and 20(2): 04.1.1. A Hausman Test Based on the Difference between Fixed Effects Two-Stage Least Squares and Error Components Two-Stage Least Squares-Solution. Econom. Theory 2005, 21, 483-484. [CrossRef]

(C) 2019 by the authors. Licensee MDPI, Basel, Switzerland. This article is an open access article distributed under the terms and conditions of the Creative Commons Attribution (CC BY) license (http:/ / creativecommons.org/licenses/by/4.0/). 